\title{
HEALTH-PRESERVING COMPETENCE IN THE SYSTEM OF PROFESSIONAL TRAINING OF PRESCHOOL TEACHERS
}

\author{
Kalichak Yu. L.
}

\section{INTRODUCTION}

One of the activities of the whole society is to preserve the health of preschool children, because only healthy children are able to properly absorb the knowledge and in the future are able to engage in community service.

It is in childhood that important basic locomotory skills and abilities, motor experience and all human motor activity are formed. The development of scientific issues on the problem of health of preschool children is a necessity, and the stimulating factor and condition for the development of all areas is the physical activity of children.

From childhood, it is necessary to form the need to maintain their own health as long as the body is plastic and easily exposed to the environment. Children show a desire to be healthy, grow up beautiful and active, be able to serve and behave so as not to harm themselves or others.

At the present stage of development of education, there are several concepts of physical development of preschool children, aimed at maintaining their health. The philosophy of a program is based on a certain view of the authors on the child, on the patterns of its development, and, consequently, on the creation of conditions that promote the formation of personality, preserve its identity and reveal the creative potential of each pupil. The development of children's motor activity should take the form of their involvement in physical culture as a natural component of human culture.

The need to consider the problem of physical education and development of preschool children is caused by the low level of the general functional state of their body by the low efficiency of the organization of their physical education. The primary task is to develop a concept for the transformation of the national system of physical education of children, which would facilitate the coordination of efforts of universities, institutions and leading experts in this field.

In the early $21^{\text {st }}$ century, the indicator of civilization of society, the main criterion for the effectiveness of all its spheres is a person, their life and health, i.e. the highest human values. 
This is confirmed by the most important strategic objectives identified by the national program "Education (Ukraine of the XXI century)"1 and "Children of Ukraine", the National Doctrine of Education $^{3}$ and the program "Health of the Nation", comprehensive human development, the formation of his spiritual, mental and physical health. Particular emphasis is placed on the priority of forming a responsible attitude to health as the highest individual and social value. These tasks are reflected in the Constitution of Ukraine ${ }^{5}$, the Law of Ukraine "On Education", the concept of national security of Ukraine", which provides for ways to improve the process of preserving, strengthening and shaping the health of the younger generation and their effective implementation in the life of each individual.

In view of this, the problem of formation of health-preserving competence in educators of preschool educational institutions is relevant and has undeniable theoretical and practical significance.

The implementation of the competence approach in the field of education in general, and in higher professional education in particular, meets the basic principles of education reform in Ukraine. The research of I. Anokhina ${ }^{8}$ D. Voronin', I. Zimnyaya ${ }^{10}$, G. Meshko ${ }^{11}$,

1 Державна національна програма «Освіта» («Україна XXI ст.»). URL: https://zakon.rada.gov.ua/laws/show/896-93-\%D0\%BF/print.

2 Національна програма «Діти України». URL: https://zakon.rada.gov.ua/ laws/show/63/96\#Text.

3 Національна доктрина розвитку освіти. URL: https://zakon.rada.gov.ua/ laws/show/347/2002\#Text.

4 Міжгалузева комплексна програма «Здоров’я нації» на 2002-2011 pр. URL: https://zakon.rada.gov.ua/laws/show/14-2002-\%D0\%BF\#Text.

5 Конституція України. URL: https://zakon.rada.gov.ua/laws/ show/254\%D0\%BA/96-\%D0\%B2\%D1\%80\#Text.

${ }^{6}$ Про освіту : Закон України. URL: https://zakon.rada.gov.ua/laws/show/214519\#Text.

7 Про національну безпеку України : Закон України. URL: https://zakon.rada.gov.ua/laws/show/2469-19\#Text.

8 Анохина И. Приобщение дошкольников к здоровому образу жизни : методические рекомендации. Ульяновск : УИПК-ПРО, 2007. 80 с.

9 Воронін Д. Формування здоров'язберігаючої компетентності студентів вищих навчальних закладів засобами фізичного виховання : автореф. дис. ... канд. пед. наук: 13.00.07. Херсон, 2006. 20 с.

10 Зимняя И. Ключевые компетентности как результативно-целевая основа компетентностного подхода в образовании. Авторская версия. Москва : Исследовательский центр проблем качества подготовки специалистов, 2004. $42 \mathrm{c.}$ 
V. Omelyanenko ${ }^{12}$, N. Tamarska ${ }^{13}$ and others enables singling out the competence of health care as an important component of the key competencies of the future teacher. Their work lays the foundations for understanding health competence as an integral quality of personality that affects both professional and personal components of human life.

N. Denysenko ${ }^{14}$, G. Belenka ${ }^{15}$, O. Bohinich ${ }^{16}$, A. Koshel ${ }^{17}$ and others touched upon certain aspects of the problem of formation of healthpreserving competence in future educators of preschool educational institutions. But the problem of formation of health-preserving competence in educators of preschool education institutions remained outside the scope of the study.

Problems of maintaining health by means of physical education of preschoolers are reflected in the works of N. Doronova ${ }^{18}$, L. Wenger $^{19}$ and others.

11 Мешко Г. Формування компетентності здоров'язбереження у майбутніх педагогів. Професійні компетениії та компетентності вчителя : матеріали Регіонального науково-практичного семінару. Тернопіль : Вид-во ТНПУ ім. В. Гнатюка. 2006. С. 17-21.

12 Омеляненко В. Педагогіка. Завдання і ситуації. Практикум. Київ : Знання, 2006. 423 c.

13 Тамарская Н. Управление учебно-воспитательным процессом в классе (здоровьесберегающий аспект) : учебно-методическое пособие для учителя. Калининград : Изд-во КГУ, 2002. 31 с.

14 Денисенко Н. Компетентностный подход в структурирование учебной дисциплины «теория и методика физического воспитания» как важная предпосылка для повышения качества подготовки учителя. Молодий вчений. 2018. Вип. 1. С. 296-300.

15 Бєлєнька Г. Сучасні підходи до питань формування професійної компетентності майбутніх вихователів дітей дошкільного віку. Оновлення змісту, форм та методів навчання і виховання в закладах освіти. 2012. Вип. 5. C. 99-102.

16 Богініч О. Основні механізми формування мотивації у майбутніх вихователів до фізкультурно-оздоровчої роботи 3 дошкільниками. 3бірник наукових праџь Уманського державного педагогічного університету імені Павла Тичини. 2009. Вип. 2. С. 38-47.

17 Кошель А. Здоров'язбережувальна діяльність майбутніх вихователів дошкільних навчальних закладів у процесі професійного становлення. Вісник Чернігівського національного педагогічного університету імені Т.Г. Шевченка. Серія «Педагогічні науки». 2013. Вип. 110. С. 235-237.

18 Радуга. Примерная основная образовательная программа дошкольного образования / Т. Доронова и др. Москва : Просвещение, 2006. 191 с.

${ }^{19}$ Венгер Л., Мухина В. Психология : монография. Москва : Просвещение, $1988.336 \mathrm{c}$. 
The purpose of the article is to investigate the state of development of the problem of formation of health competence in kindergarten teachers and to reveal the essence of the main categories.

To achieve this aim, the following objectives were set:

1. Investigate the peculiarities of the formation of health-preserving competence of preschool teachers.

2. Find out the main factors of formation of health-preserving competence and the essence of the categories "health-preserving competence", "health-preserving technologies", "health-preserving environment".

3. Analyze the content and organizational aspects of the formation of health competence as an important component of the professional readiness of the educator of preschool education.

The following methods were used during the study:

a) theoretical: analysis, systematization and generalization of theoretical data presented in pedagogical, psychological and methodological literature;

b) empirical: individual and group conversations, observations, surveys, problem solving, analysis of children's products.

\section{The main components of health-preserving competence of preschool teachers at the present level of preschool education}

The formation of health-preserving competence by means of physical education is especially important for pedagogical students, because a modern preschool specialist must have not only a high level of professional training, but also good health. The concept of "healthpreserving competence" can be formulated as a certain level of medical and valeological literacy of the student, the state of social well-being, and the degree of development of creative forces, physical, mental and intellectual abilities, manifested in the organization of his life, in relation to himself and others, to wild nature.

Health-preserving competence presupposes not only medical and valeological informativity, but also application of the acquired knowledge in practice, mastery of methods of health promotion and disease prevention. Formation of the orientation on preservation and strengthening of health is an integral component of health-preserving competence of future teachers.

Health-preserving competence can be exercised in the form of preventive measures and the use of health-preserving technologies by people who know the laws of the health-preserving process. 
The formation of health-preserving competence involves: the conceptual basis of knowledge about the health of modern man; instilling a healthy lifestyle; safe behavior skills; cultivation of health-promoting, health-preserving, vital activity; acquisition of knowledge about health and its components; formation in the personality of the value relation to the environment, to people, to itself; application of methods of complex health assessment and a system of practical skills that ensure the preservation and strengthening of health; use of knowledge about preservation and strengthening of health, about self-regulation and self-correction; possibility of first aid; o the ability to prevent injuries.

The problem of training highly qualified pedagogical staff is one of the important tasks of the national preschool education and is connected with the observance of the proper level of health and the formation of healthpreserving competence in preschool specialists.

As I. Zyazyun notes, "the main goal of higher education should be the formation of a holistic and purposeful personality, ready for free humanistic oriented choice and individual intellectual effort with multifunctional competencies" $" 20$.

The problem of pedagogical competence of preschool specialists is most thoroughly covered in the monograph of G. Belenka. The author believes that it is time to change the established approaches to understanding the essence of the concept of "professional (professional) competence of the educator". It is impossible to consider the professional competence of a preschool teacher only as a cognitive component of pedagogical professionalism and the basis of professional thinking, consciousness and self-awareness ${ }^{21}$.

The formation of competencies is inextricably linked to a certain type of knowledge organization. After all, it is not about the amount of knowledge, not about their strength, but "how individual knowledge is organized, how reliable they are as a basis for making effective decisions regarding a particular situation" - emphasizes M. Kholodnaya ${ }^{22}$.

She believes that the knowledge of a competent person must meet the following requirements: diversity; structure; categorical nature; possession of not only subject but also procedural knowledge; availability of

20 Зязюн I. Педагогічна майстерність: проблеми, пошуки, перспективи: монографія. Київ ; Глухів : РВВ ГДПУ, 2005. 118 с.

21 Бєлєнька Г. Вихователь дітей дошкільного віку: становлення фахівця в умовах навчання : монографія. Київ : Світоч, 2006. 304 с.

22 Холодная М. Психология интеллекта: парадоксы исследования : монография. 2-е изд., перераб. и доп. Санкт-Петербург : Питер, 2002. 272 с. 
knowledge about one's own health and knowledge related to personal experience; flexibility; efficiency; effectiveness ${ }^{23}$.

The category of health is closely related to the concept of health competence. The phenomenon of health has been the subject of research by many scientists and has been considered in several aspects: philosophical, medical-biological and socio-pedagogical; M. Amosov ${ }^{24}$, E. Weiner $^{25}$, Y. Lisitsyn ${ }^{26}$, and others studied its essence. Research has shown that the category of "health" is defined by researchers as the integrative quality of a full harmonious human existence in all its dimensions and aspects.

Health is a multifaceted concept. This is not only the absence of disease, but also a comfortable psychological well-being, good mood, high level of adaptation, well-being. That is, it is a harmonious combination of physical, mental, spiritual and social health as a result of self-discipline, self-knowledge, and self-realization based on a persistent need to be healthy.

According to modern scientific approaches, the structural components of health are determined: mental health - the state of the mental sphere of man, which is characterized by general mental comfort, provides adequate regulation of behavior and due to the needs of biological and social nature; physical health, which is considered as the current state of functional organs and systems of the body; spiritual health is a state of the spiritual world of an individual, his perception of the components of the spiritual culture of mankind, education, science, art, religion, morality, and ethics; social health is a system of values, guidelines and motives for behavior in the social environment.

All competencies are interconnected and subject to health care.

Health competence involves maintaining one's own physical, social, mental and spiritual health and the health of one's surroundings. It includes: life skills that promote physical health (nutrition, physical activity, hygiene and rest); skills that promote social health (communication, compassion, conflict resolution, joint activities and cooperation); skills that promote spiritual and mental health (self-

23 Холодная М. Психология интеллекта: парадоксы исследования : монография. 2-е изд., перераб. и доп. Санкт-Петербург : Питер, 2002. 272 с.

24 Амосов Н. Здоровье и счастье ребенка : монография. Москва : Академия, 1997. $361 \mathrm{c}$.

25 Шапар В. Психологічний тлумачний словник. Харків : Прапор, 2004. $640 \mathrm{c}$

26 Лисицын Ю. Слово о здоровье : монография. Москва : Академия, 2006. 192 c. 
awareness and self-esteem, problem analysis and decision making, definition of life goals and programs, self-control, motivation for success and training of will).

Based on the above, quality training of future educators of preschool education is becoming a strategic area, the implementation of which should be the focus and priority of the development of education and health, as these factors determine the level of health and culture of a healthy lifestyle of each child. At the present stage, the issues of restoring the importance of physical culture, reducing morbidity among children, improving health, improving physical and mental fitness, developing creative abilities and skills of independent scientific knowledge and selfeducation to improve the level of professional training are relevant. That is, the formation, preservation and restoration, and then the transfer of health to future children - the main goal of our society and, above all, the system of preschool education.

N. Denysenko ${ }^{27}$ notes that in order to form health, you need to know clearly how it is laid, preserved and destroyed, as well as the fact that health depends on many factors, relationships in the family. Preschool teachers play a significant role in shaping, maintaining and promoting health.

I. Anokhina has a similar view on the formation of health-preserving competence. She considers the formation of health-preserving competence as a willingness to independently solve problems related to maintaining, strengthening and maintaining the health of their own as well as of others $^{28}$.

Researcher D. Voronin testifies that in order to solve this problem it is necessary to form in students a stable motivation for a healthy lifestyle, to implement a set of health measures aimed at realizing the value of their health. The development of health-preserving competence through physical education is especially important for such a category of young people as students of higher pedagogical education, as a modern specialist must have not only a high level of professional training, but also good health. The concept of "health competence" can be formulated as a certain level of medical and valeological literacy of the student, the state of social well-being, the degree of development of creative forces, physical, mental

27 Денисенко Н. Компетентностный подход в структурирование учебной дисциплины «теория и методика физического воспитания» как важная предпосылка для повышения качества подготовки учителя. Молодий вчений. 2018. Вип. 1. С. 296-300.

28 Анохина И. Приобщение дошкольников к здоровому образу жизни : методические рекомендации. Ульяновск : УИПК-ПРО, 2007. 80 с. 
and intellectual abilities, expressed in the organization of his life, in relation to himself, others, to nature.

Developing this idea, D. Voronin argues that health competence involves not only medical and valeological informativity, but also the application of acquired knowledge in practice, mastery of methods to promote health and disease prevention. Formation of the orientation of thinking on preservation and strengthening of health is an integral component of health-preserving competence of future specialists ${ }^{29}$.

\section{The essence of the categories "health-preserving competence",} "health-preserving technologies", "health-preserving environment"

The category "health-preserving competence" provides a set of physical and intellectual qualities and human characteristics necessary for independent and effective resolution of various life situations, creating better conditions for themselves, their health in constructive interaction with others.

According to N. Tamarska, the essence of the concept of "healthpreserving competence" is manifested in the implementation of preventive measures and the use of health technologies by people who know the laws of health care c $^{30}$.

Under the concept of "health-preserving competence" V. Khiminets understands the characteristics, properties of the student, aimed at maintaining physical, social, mental and spiritual health - their own and the environment ${ }^{31}$.

The formation of health-preserving competence primarily involves:

- conceptual foundations of knowledge about the health of modern man, the development of a culture of mental and physical health;

- instilling a healthy lifestyle (psychological, pedagogical and medical and hygienic aspects);

- safe behavior skills;

- cultivation of healthy, health-preserving, vital activity;

- operating with knowledge about health and its components;

29 Воронін Д. Формування здоров'язберігаючої компетентності студентів вищих навчальних закладів засобами фізичного виховання : автореф. дис. ... канд. пед. наук: 13.00.07. Херсон, 2006. 20 с.

30 Тамарская Н. Управление учебно-воспитательным процессом в классе (здоровьесберегающий аспект) : учебно-методическое пособие для учителя. Калининград : Изд-во КГУ, 2002. 31 с.

${ }^{31}$ Химинець В. Компетентнісний підхід до професійного розвитку вчителя. Закарпатський інститут післядипломної педагогічної освіти. URL: http://zakinppo.ua/2010-01-18-13-44-15/233-2010-08-25-07-10-49. 
- formation of personal values in relation to the environment, to people, to oneself;

- possession of methods of comprehensive health assessment and a system of practical skills that ensure the preservation and strengthening of health;

- use of knowledge about maintaining and strengthening health, selfregulation and self-correction;

- mastering the methods and means of first aid;

- ability to carry out injury prevention.

Closely related to the concept of "health competence" are the concepts of "health technologies" and "health formations".

T. Boychenko emphasizes that the essence of health technologies is to carry out appropriate corrective, psychological, pedagogical, rehabilitation measures to improve the quality of life of the individual: the formation of a higher level of health, healthy lifestyle skills, professional activities and its minimum physiological "value",32.

According to O. Moskovchenko, health-preserving technologies are a set of scientific knowledge, tools, methods and techniques that allow to assess the functional and psycho-physiological parameters of an individual's health; based on the assessment of health parameters to select an adequate training load that allows to increase the functional capabilities of the body in order to move it to a new level of functioning to preserve and strengthen creativity, increase efficiency and social activity, solving problems of sports fitness. There are health-preserving technologies - a set of tools and measures aimed at strengthening the psychophysical and psychological health of children and health-forming technologies - are psychological and pedagogical technologies, programs, methods aimed at educating preschool children in health culture, personal qualities that contribute to its preservation and strengthening, the formation of the idea of health as a value, motivation to lead a healthy lifestyle ${ }^{33}$.

The research does not cover all aspects of the problem. Further study and research is needed on the use of innovative technologies in the system of professional training of educators to ensure the health-preserving competence of preschool teachers.

32 Бойченко Т. Здоров'язберігаюча компетентність як ключова в освіті України. Основи здоров'я і фізична культура. 2008. Вип. 11-12. С. 6-7.

33 Московченко О. Оптимизация физических нагрузок на основе индивидуальной диагностики адаптивного состояния у занимающихся физической культурой и спортом (с применением компьютерных технологий) : автореф. дис. ... докт. пед. наук. Москва, 2008. 62 с. 
The implementation of the tasks of physical education and rehabilitation of preschoolers depends on the professional competence of the educator in the field of health care.

Based on this generalized definition, in the structure of healthpreserving competence it is possible to single out a motivational component, which provides a focus on awareness of health values, the presence of stable motives for health-preserving activities; cognitive - as a set of medical-biological, psychological-pedagogical, valeological and specialized knowledge; activity - involves the inclusion on a parity basis of health in all aspects of teaching through the formation of appropriate professional skills and abilities.

In addition, the relationship between personal (responsible attitude to one's own health) and professional aspects (awareness of the health values of all subjects of the educational process and the ability to preserve it) allows us to consider health competence as universal. In this context, it allows teachers to focus on the health of all subjects of the educational process (teachers, children and parents), not limited to solving problems of physical culture and health.

At present, the problem of health care has gone beyond the professional activities of only a preschool teacher or a physical education instructor. Each teacher must carry out their own professional activities, taking into account the implementation of tasks to preserve and promote the health of students; this applies to both substantive and organizational aspects. In view of this, the problem of forming the readiness of the educator to ensure health activities becomes especially relevant.

We are convinced that the high level of health competence of educators ensures the appropriate level of their health activity, and this, in turn, contributes to the formation of health competence of preschool children.

Based on the synthesizing nature of the understanding of the concept of health competence, we project the content of general professional competences in the field of "Preschool education", aimed at implementing professional functions in the field of preservation and promotion of health.

\section{The importance of health-preserving competence in the professional training of preschool teachers}

Namely, the ability to apply knowledge and skills in medical, pedagogical and psychological methods of influencing the teaching staff and the team of students:

- be able to diagnose the child's temperament, create a psychological and pedagogical characteristics together with a psychologist;

- determine the level of team development; 
- have the technology to correct the psycho-emotional state of the individual depending on age, gender and socio-cultural development;

- ability to create programs for children's development, taking into account the basic principles of health care;

- understand the uniqueness and significance of preschool childhood for the further development of personality;

- be able to use advanced pedagogical experience in the field of physical culture and rehabilitation activities;

- specify the goals and objectives of education and development of children in accordance with their needs, interests and inclinations);

- the ability to teach children to assess their physical condition, to identify harmful factors influencing the state of health, to use available means to maintain and promote health;

- teach children the basics of control over their own well-being and functional state both during organized learning and in everyday activities;

- to acquaint with features of influence of physical exercises, hygienic factors, forces of the nature and other expedient means of preservation and strengthening of health;

- ability to establish meaningful cooperation of preschool education institutions with families;

- be able to use technologies of cooperation with adults, select them according to the situation;

- carry out educational activities on the culture of health and healthy living with different segments of the population;

- take into account the available material and technical conditions and opportunities for the use of natural resource technologies;

- ability to ensure the implementation of structural and substantive and organizational and methodological aspects of physical culture and health, recreational and sports and educational activities;

- together with a doctor of therapeutic physical culture to determine the dosage of physical activity and develop schemes of therapeutic gymnastics complexes;

- conduct individual and group classes in therapeutic and hygienic gymnastics;

- involve children in the basics of health care, teach them to explore their own well-being; be able to get acquainted with appropriate methods of influencing the functional state of the organism, to prevent the occurrence of fatigue; 
- monitor the effectiveness of exercise; it is advisable to use methods to assess the state of physical development, motor fitness, mental and physical performance ${ }^{34}$.

The list of competencies and skills that ensure readiness for professional activity in the institution of preschool education of the graduate of the "bachelor" level of the specialty "Preschool education":

- understanding and awareness of the laws in the field of health and childhood;

- adhere to the state strategy in the field of health protection and promotion in its own professional activity;

- formation of valeological thinking and promotion of creative selfrealization of the child's personality;

- orientation in the socio-cultural experience of mankind in relation to health practices with children;

- promoting the improvement of the quality of life of preschoolers in the cultural and spiritual sphere;

- expedient use of all natural potential of various means of physical culture;

- ability to analyze the optimal development and differences in the development of the child's body;

- understanding of the anatomical structure and functions of the child's body;

- ability to determine the anatomical structure by external signs;

- be aware of the interdependence of the impact of the deterioration of the functions of the child's body on the anatomical structure of the body;

- understanding of the processes that take place in the child's body when he learns to control the motor functions of his body, use this knowledge to develop motor skills and abilities;

- taking into account the constant relationship and influence of different areas (motor, cognitive, emotional, social) development of the child's personality;

- understanding of the general principles and mechanisms of processes that worsen the state of health, possible reactions to damage, recovery and recovery in the context of practical activities;

- ability to determine the purpose and objectives of physical culture and health activities;

34 Овчарук О. Компетентнісний підхід у сучасній освіті: світовий досвід та українські перспективи : монографія. Київ : К.І.С., 2004. 112 с. 
- to provide health-preventive and valeological orientation of the educational process;

- use the most appropriate health technologies and methods of physical therapy in accordance with the state of health and the stage of the rehabilitation process;

- create a list of material, technical and methodological support of the physical culture and health process;

- plan measures to support children with deteriorating health, adequate to the modern goals of preschool education;

- provide a holistic approach to the use of physical culture;

- evaluate the health and training effect of physical education classes; systematically apply the assessment of the effectiveness of the health process;

- diagnose the health of children;

- be able to apply adequate methods to study the state of health of children in the classroom and in everyday activities;

- forecast the results of rehabilitation activities, identify areas and tasks that need correction;

- to find out the reasons of typical mistakes at rehabilitators, to define ways for their elimination;

- adapt the educational process to the needs of children, plan activities to improve the culture of health;

- be able to use innovative technologies to form the basics of health culture in children;

- use various forms of joint physical culture and health activities with parents;

- use psychological and pedagogical methods to create a favorable microclimate;

- take into account the cultural and speech differences between children and parents; to develop own style of pedagogical communication according to a situation, the purposes and tasks;

- it is advisable to use terminology;

- be able to explain to parents the appropriateness of health measures ${ }^{35}$.

The analysis of research on the problem of preparing teachers for activities in the field of health care allows us to identify the main provisions that can serve as a basis for designing the process of formation of health care competence. In the system of professional training of

35 Овчарук О. Компетентнісний підхід у сучасній освіті: світовий досвід та українські перспективи : монографія. Київ : К.І.С., 2004. 112 с. 
educators for health activities, there are several areas, namely: targeted (focus on providing value orientations for a healthy lifestyle); semantic (provision of anatomical-physiological, valeological, psychologicalpedagogical and physical culture-health aspects of health care); diagnostic (mastering the basics of monitoring the quality and effectiveness of physical culture and health orientation of the educational process).

The implementation of these areas can be ensured by the introduction of the necessary conditions, in particular: focus on the values of health and as a consequence of the recognition of health competence as one of the important components of the overall; formation of health-preserving competence with the use of innovative educational technologies; use of interdisciplinary links, ensuring interpenetration and mutual enrichment of tasks of educational and health areas; introduction of educational subjects (special courses, special seminars, etc.) focused on education of culture of health of the person; establishing a close connection between theoretical training and practical implementation of acquired professional knowledge and skills in the field of health care.

Deepening of training is provided at the expense of introduction of professionally-oriented special courses and special seminars which are planned each new academic year taking into account interests of students - future tutors.

Thus, the formation of health-preserving competence of future educators is an important task in the system of professional training, as it includes readiness to carry out qualified activities in the field of health care in professional and personal aspects, on the basis of awareness of health values, motivation of healthy lifestyle and unity of physical, mental and social health of all subjects of the educational process.

The priority of the problem of health care is emphasized in the National Strategy for Education Development of Ukraine ${ }^{36}$, the Law of Ukraine on "Higher Education" 37 and other regulations. In particular, it is stated that the need for health is fundamental in the system of life values of each person, without which the self-actualization of the individual is not possible. First of all, it concerns future educators of preschool children, who are called to help solve the problem of the nation's health and changes in society, in the lives of people, families, to enable people to develop their full potential, to enrich their lives. Therefore, preserving and strengthening

36 Національна доктрина розвитку освіти. URL: https://zakon.rada.gov.ua/ laws/show/347/2002\#Text.

${ }^{37}$ Про освіту : Закон України. URL: https://zakon.rada.gov.ua/laws/show/214519\#Text. 
the health of preschool children is one of the main tasks of the social program of our state. Priority is given to the social order for an educator who possesses health-preserving technologies of teaching and education, is able to organize innovative activities in the conditions of health-preserving educational process and to develop health-preserving competence of preschool children.

Today, the problem of human health in the context of universal values is becoming increasingly important. There is a wide public response to the understanding that among the problems, the solution of which should not depend on socio-political conflicts, the central issue is the problem of children's health, without the solution of which there is no future in the country. The problem of health of preschool children is becoming a priority for the development of modern education, the strategic goal of which is to ensure the comprehensive and harmonious development of man as a person and the highest value of society, development of mental and physical abilities, and education of high moral qualities.

Among the main directions of modernization of the content of preschool education is the creation and introduction of innovative technologies for the development, education and upbringing of preschool children. The root cause of the negative trends in the health of the younger generations is the contradiction between the needs of children and the ways in which they are brought up and educated. Therefore, the task of preserving and strengthening the health of children must be solved, first of all, by pedagogical means. Such, in our opinion, are health-saving technologies aimed at solving the problems of strengthening the health of children, increasing health resources. They correspond to the conceptual provisions for the formation of a healthy lifestyle of the child, namely: the priority of health over other values; health is the most important value of life; valeological approach; the principle of a healthy lifestyle, adherence to the regime (rational organization of the child's life); environmental pedagogy; the principle of prevention of disorders in the health of children; the principle of naturalness; variety of forms and methods of valeological education; the principle of self-regulation; rejection of negative health effects; the principle of conservation and training technologies. The use of the concept of "technology" in the field of education, the pedagogical process is due to the widespread introduction of a technological approach. The approach opens up new possibilities.

The technological approach to teaching involves precise instrumental management of the pedagogical process and guaranteed achievement of certain learning goals. In the context of considering the technologization of the learning process is of particular value psychological and valeological 
validity and instruction of the learning process, i.e. any technology should be based on the strategic objectives of modern education - improving the pedagogical process and providing appropriate conditions for child development and formation and improvement of health. In the process of implementing health technologies, educators need to take into account the priorities of health activities: cultivating in children a conscious attitude to their own health (physical, mental and social) as a whole, improving the adaptive capacity of the child's body; consolidation by the teacher of effects of separate improving actions in the form of constant psychosomatic states of the child which further will be able to be reproduced in a mode of self-development; formation of arbitrary regulation of vital functions of the organism, development of creative imagination; education of the child's ability to self-perception of his own body structure in possible forms; instilling in children the skills of mutual assistance in appropriate situations and the basics of self-correction; activation and development of cognitive interests in one's own organism; formation of valeological ideas in children; development of emotional compassion for other people; introduction of a healthy lifestyle as the basis of daily activities.

The specifics of the organization of the pedagogical process of preschool education allows us to say that health technologies are the most effective in terms of the degree of impact on children's health. Their main feature is considered to be a comprehensive approach to solving health problems, the use of psychological and pedagogical methods and techniques. Analysis of research in the field of technologization of the educational process, ensuring its health direction, suggests that the concept of "healthy educational technologies" has several aspects.

This concept is defined as a systemically organized set of programs, methods, techniques, tools and forms of organization of the educational process that does not harm the health of its subjects; as a qualitative characteristic of pedagogical technologies according to the criteria of their influence on the health of teachers and pupils; as a technological basis of health pedagogy. Given this, we can distinguish three subgroups: organizational and pedagogical technologies that determine the structure of the educational process, prevent fatigue, the phenomenon of hypodynamy and other maladaptive states; psychological and pedagogical, related to direct professional activity, including psychological and pedagogical support of the educational process, pedagogical technologies, including programs for the formation of children's knowledge of the basics of a healthy lifestyle, health culture. 
Health-preserving technologies in modern preschool education are aimed at solving the urgent educational task - preserving and strengthening the health of the subjects of the educational process. Implementation of health technologies at the child's level - ensuring a high level of real health of preschool pupils and education of valeological culture as a set of conscious attitude of the child to his own health and the health of others, knowledge about his health and skills preservation and strengthening of valeological competence, which allows the child to independently and effectively solve problems of healthy lifestyle and safe behavior associated with the provision of basic (in accordance with the age capabilities of children) medical, psychological care. At the adult level, it is the promotion of a culture of health, including a culture of occupational health, educators and valeological education among various sections of the population.

In our opinion, the classification of health technologies should correspond to the peculiarities of functioning and structural components of the health environment. These are the following types of technologies: treatment and prevention; physical culture and health; technologies aimed at ensuring the socio-psychological well-being of the child; health and health enrichment of teachers; valeological education of parents; health education technologies.

The components of treatment and prevention technologies are: organization of monitoring the health of preschool children; development of recommendations for optimizing children's health; organization and control of children's nutrition; implementation of medical and pedagogical control over the physical activity of children in the process of physical education; control over the organization and conduct of special hardening procedures; organization of preventive measures; organization of control and assistance in compliance with sanitary and hygienic requirements; active participation in the organization of the health environment.

The components of physical culture and health technologies include: formation of motor skills, development of physical qualities, optimization of motor activity; formation of physical culture of the child; development of the respiratory system; prevention of posture disorders and flat feet; educating the need for daily physical activity and taking care of their own health. Technologies for ensuring the social and psychological well-being of the child are represented by technologies for psychological and psychological-pedagogical support of the child's development. 


\section{Priority of application of health-preserving technologies in the process of implementation of innovative educational activities with preschool children}

Technologies for health and health enrichment of teachers include technologies aimed at developing a culture of health, including the culture of occupational health, the formation of sustainable motivation to lead a healthy lifestyle. Technologies of valeological education of parents include informing by various means, non-traditional, in particular interactive forms of work with parents, master classes, trainings, etc. We are convinced that the effectiveness of the positive impact on children's health of various health technologies is determined not so much by the quality of each of the structural elements of each of them, but by the adequacy of their implementation in the educational process aimed at preserving and strengthening the health of children and educators, and compliance with the implementation of the tasks.

The choice of health technologies, according to N. Denysenko ${ }^{38}$, depends on the program of preschool education, priority educational tasks, the state of health of pupils, their interests and preferences, taking into account the focus of health products on improving the basic indicators of physical development of children. human resources (the issue of psychological readiness of educators to restructure their professional activities, the introduction of innovative technologies, self-improvement, the level of awareness of responsibility for their own health and the health of their students), logistics (availability of a separate room for physical training and health) events, sports grounds, sports corners in group rooms, physiotherapy room, phyto-rooms, rest rooms for educators, etc.), environmental factors (environmental situation in the country, region, occupancy of groups, compliance with sanitary and hygienic and san technical requirements), the existing level of cooperation with parents of pupils, their awareness of the importance of purposeful work to preserve and promote the health of children (parents should be an example for their own children), the ability to effectively monitor the effectiveness of technologies.

The introduction of health technologies should, first of all, provide comfortable conditions for the development of children's potential and prevent negative effects on the health of the stressful environment. For this

38 Денисенко Н. Компетентностный подход в структурирование учебной дисциплины «теория и методика физического воспитания» как важная предпосылка для повышения качества подготовки учителя. Молодий вчений. 2018. Вип. 1. С. 296-300. 
purpose it is necessary to consider the following requirements: to consider individual features of children; to prevent intellectual, emotional, nervous overload in the process of mastering the content of the curriculum; provide support for a favorable moral and psychological climate in the group; Emphasize the focus of the educational process not so much on its health, but on the formation of children's skills of health behavior, i.e. it is necessary to learn to overcome stress, use psychological protection and health.

In modern preschool education, health technologies have become widespread. Educators use fairy tale therapy, football gymnastics, finger gymnastics, psycho-gymnastics, breathing gymnastics, kinesioreflexotherapy, aromatherapy and phytotherapy, oxygen drinks, color therapy, various types of massage (using brushes, cones, nuts, treble, self-pointing, point, sand therapy, author's technologies, diversify work by using non-traditional equipment, etc. However, their unsystematic and episodic use is often observed, integrity in the organization of healthpreserving space is not ensured, the introduction of technology is not always preceded by diagnosis of children's health and awareness of the end result, prospects for further improvement.

The implementation of health technologies in the practice of preschool education will contribute to the formation of a child's life competence. The main indicators of competence in health care include: ideas about health, the factors that affect health and a healthy lifestyle; the importance of "health" as a universal value; the ability to track and record positive and negative changes in their own health and the health of others.

Today's preschool education can be described as the accumulation and search for new health technologies. Each preschool institution tries to create a holistic system of physical culture and health work, the most effective in certain conditions. When choosing health-preserving technologies, educators should take into account material and technical conditions (location of premises, availability of sanitary, medical, sports equipment, staffing of groups); the state of physical and mental health of children and educators (health index, morbidity rate, increased emotional tone); indicators of motor readiness of children, the integrity of health effects and stability of results, the level of their own professional competence (seek to enrich their knowledge on maintaining and promoting health, to form sustainable motives for a healthy lifestyle), the level of cooperation with parents (parents - example health behavior), environmental factors.

The problem of forming, maintaining, strengthening and restoring the health of preschool children will always be relevant. Due to social- 
democratic preconditions, economic and material constraints, ecological crisis, most families of Ukraine have children whose lives are caused by diseases or unfavorable social and psychological conditions, lack of conditions for games and activities, insufficient balanced nutrition, violation of sanitary and hygienic norms. All these reasons have a negative impact on the health of the individual. In order to strengthen the health of the individual, along with eliminating the causes of the negative impact, there is a need to form knowledge about the preservation of health.

According to the National Doctrine of Education Development in Ukraine $^{39}$ and the Law on Preschool Education ${ }^{40}$, teachers and parents must instill in their children a valued attitude to life and their own health and the lives of others as the highest individual and social value. In this regard, there is an important problem - the development of health and health-promoting technologies that would not only maximize the physical body of the child, but also form his psyche, spirituality, communication skills, i.e. strengthen health as a complex category, which includes physical, mental, spiritual and social components. Preschoolers should not only know about their own health, but also treat it emotionally, preferring the positive effects of the environment to harmful, destructive ones. A significant role in the protection and promotion of human health is played by their individual attitudes and guidelines, which are laid down in childhood by both parents and teachers.

Thus, health depends more on the individual himself, in particular on how self-aware he is. In addition to parenting, in this case, a great help is provided by the preschool institution, one of the tasks of which is to create conditions that guarantee the formation of ideas and strengthen the health of students. A conscious attitude to one's own health in preschoolers is ensured by the formation of a system of knowledge that helps to realize that the relationship between peers and adults should not be stressful, but friendly, charitable, cultural, communication should be able to manage their emotions, evaluate themselves and others, understand the motives of behavior. In addition, the child in the joint play, cognitive, work activities shows its independence.

The ability to develop a conscious attitude to health and its preservation depends on the needs of the child. By influencing the formation of needs

39 Національна доктрина розвитку освіти. URL: https://zakon.rada.gov.ua/ laws/show/347/2002\#Text.

${ }^{40}$ Про освіту : Закон України. URL: https://zakon.rada.gov.ua/laws/show/214519\#Text. 
and their satisfaction, we also influence the state and development of the child's health. This is achieved by the fact that educators and practical psychologists of our kindergarten create conditions that meet the child's need for individual emotional and value support of his personality development, which is based on the child's attention, recognition of his needs, constructive communication, success, respect, support, cooperation, activity and independence. In preschool, children are receptive and obedient, so there is a unique opportunity to form in them habits of a healthy lifestyle. Therefore, our task is that we must not only give quality knowledge to their students, but also to form in them a conscious attitude to a healthy lifestyle, to teach children to live in harmony with themselves and the world around them.

To form the value of health in preschoolers, we regularly conduct valeology classes with children, Health Days, holidays and entertainment, themed days. The formation of a healthy lifestyle in preschoolers gives us a positive result. Children realize what health is like, how their body is arranged, how people differ from each other, they form initial ideas about the senses and ways to preserve them, basic skills of basic life safety. When talking to children, we pay attention to the fact that you should take care not only of your own health, but also of the health of others. When talking about diseases, it is necessary to teach children to take into account the illness and poor physical condition of another person, disability. Such conversations help to cultivate a humane attitude to people, compassion, empathy, a desire to help. At the same time, such conversations help the child to think about the need to take care of themselves, about safety measures at home and on the street. On walks they organize humorous games with children - jump, run, without bending knees; become small, short; become bigger; get a branch on a tree, etc. By performing these exercises, the child understands why you need arms, legs, elbows, fingers and toes. In the older group, children are already able to perform a basic health analysis.

The main thing in the work of a preschool institution is to take care of the health of children, because a healthy child is more receptive to educational influences, acquires the necessary skills faster, and adapts better to changes in the surrounding reality. The problem of children's health is the lever of educational work carried out by parents and teachers, and the strategic goal is the education and development of a cheerful personality, enriched with knowledge about oneself, ready for creative activity, whose behavior meets universal moral standards. And knowledge, understanding and implementation of the basics of a healthy lifestyle these are the three key points on which will depend the fullness and life 
expectancy of each individual, the whole generation and all future generations of people. Therefore, the value of health is the universal value of humanity.

Thus, it is necessary from the first years of life to form in children the foundations of valeological culture, based on valeological knowledge and awareness, a deep interest in healing their own body, the desire to lead a healthy lifestyle, mastery of health and behavioral skills, responsibility for their own health and that of other people.

\section{CONCLUSIONS}

1. The analysis of research on the problem of preparing teachers for activities in the field of health care allows us to identify the main provisions that can serve as a basis for designing the process of formation of health care competence. In the system of professional training of educators for health activities, there are several areas, namely: target (focus on providing value orientations for a healthy lifestyle); semantic (provision of anatomical-physiological, valeological, psychological-pedagogical and physical culture-health aspects of health care); diagnostic (mastering the basics of monitoring the quality and effectiveness of physical culture and health orientation of the educational process).

2. The implementation of these areas can be ensured by the introduction of the necessary conditions, in particular: focus on the values of health and as a consequence of recognizing health competence as one of the important components of the overall; formation of health-preserving competence with the use of innovative educational technologies; use of interdisciplinary links, ensuring interpenetration and mutual enrichment of tasks of educational and health areas; introduction of subjects (special courses, special seminars, etc.) focused on the education of personal health culture; establishing a close link between theoretical training and practical implementation of acquired professional knowledge and skills in the field of health preservation.

The problem of formation of "health preserving competence" is insufficiently studied; there is no unanimity in a few interpretations, the concept of "health preserving competence" which is explained by the multifunctional nature of this term. Among the components of key competencies related to the problem of preserving and strengthening 
human health, scientists D. Voronin ${ }^{41}$, I. Zymnyaya ${ }^{42}$, V. Sergienko ${ }^{43}$ allocate health-preserving competence.

3. In highlighting the problem of health in the field of preschool education, researchers focus on certain personal characteristics of the educator, the peculiarities of professional activities, including pedagogical technologies, which are manifested primarily in caring for the health of preschool children.

Thus, the formation of health-preserving competence of future educators is an important task in the system of professional training, as it includes readiness to carry out qualified activities in the field of health care in professional and personal aspects, on the basis of awareness of health values, motivation of healthy lifestyle and unity of physical, mental and social health of all subjects of the educational process.

Thus, the formation of "health competence" does not imply unanimity in a few interpretations, which is explained by the multifunctional nature of the definition.

Health-preserving competence has the following components: rational nutrition, optimal physical activity, sanitary and hygienic regime of work and rest; effective communication, absence and resolution of conflicts, behavior in conditions of pressure, threats, discrimination, joint activities and cooperation; self-awareness and self-assessment, analysis of problems and decision-making, definition of life goals and programs, self-control, motivation for success and training of will.

The formation of health-preserving competence involves: the conceptual basis of knowledge about the health of modern man; instilling a healthy lifestyle; safe behavior skills; cultivation of health-promoting, health-preserving, active life behavior; acquisition of knowledge about health and its components; formation in the personality of the value relation to the environment, to people, to itself; application of methods of complex health assessment and a system of practical skills that ensure the preservation and strengthening of health; use of knowledge about

41 Воронін Д. Формування здоров'язберігаючої компетентності студентів вищих навчальних закладів засобами фізичного виховання : автореф. дис. ... канд. пед. наук: 13.00.07. Херсон, 2006. 20 с.

42 Зимняя И. Ключевые компетентности как результативно-целевая основа компетентностного подхода в образовании. Авторская версия. Москва : Исследовательский центр проблем качества подготовки специалистов, 2004. $42 \mathrm{c}$.

${ }^{43}$ Сергієнко В. Проблеми виховання студентської молоді. Вища школа. 2010. Вип. 7-8. С. 75-79. 
preservation and strengthening of health, about self-regulation and selfcorrection; possibility of first aid; ability to carry out injury prevention.

In the field of preschool education, the problem of health care emphasizes certain personal characteristics of the educator, the peculiarities of professional activity, in particular pedagogical technologies, which are manifested in particular in caring for the health of preschool children.

\section{SUMMARY}

The article analyses the peculiarities of formation of health-preserving competence of preschool teachers based on psychological and pedagogical sources are analyzed. The urgency of this problem in the modern system of preschool education of Ukraine is substantiated. The main factors of formation of health preserving competence and the essence of the categories "health preserving competence", "health preserving technologies", "health preserving environment" are clarified.

The article analyzes the content and organizational aspects of the formation of health preserving competence as an important component of the professional training of preschool teachers. The multifunctional nature of the concept of "health preserving competence" is revealed, its components and directions of formation are characterized.

Health preserving competence is seen as an integral, dynamic personality trait that manifests itself in the ability to organize and regulate health preserving activities. The health preserving competence of a teacher is supported by a set of professionally oriented knowledge, skills, attitudes and values aimed at preserving and strengthening the health of both teachers and children.

The directions in the system of professional training of preschool teachers and the conditions that will ensure the implementation of important professionally-oriented tasks of health preserving competence are described.

Thus, the formation of health-preserving competence of future educators is an important task in the system of professional training, as it includes readiness to carry out qualified activities in the field of health care in professional and personal aspects, on the basis of awareness of health values, motivation of healthy lifestyle and unity of physical, mental and social health of all subjects of the educational process.

It has been found that the selection of health technologies should correspond to the peculiarities of functioning and structural components of the health environment, namely: treatment and prevention; physical culture and health; technologies aimed at ensuring the socio-psychological well- 
being of the child; health and health enrichment of teachers; valeological education of parents; health education technologies.

It has been established that health technologies are actively used in modern kindergartens. Educators practice fairy tale therapy, football gymnastics, finger gymnastics, psycho-gymnastics, breathing gymnastics, kinesioreflexotherapy, aromatherapy and phytotherapy, color therapy, various types of massage, music therapy, game training, sand therapy, etc.

\section{References}

1. Амосов Н. Здоровье и счастье ребенка : монография. Москва : Академия, 1997. $361 \mathrm{c.}$

2. Анохина И. Приобщение дошкольников к здоровому образу жизни : методические рекомендации. Ульяновск : УИПК-ПРО, 2007. $80 \mathrm{c}$.

3. Бєлєнька Г. Вихователь дітей дошкільного віку: становлення фахівця в умовах навчання : монографія. Київ : Світоч, 2006. 304 с.

4. Бєлєнька Г. Сучасні підходи до питань формування професійної компетентності майбутніх вихователів дітей дошкільного віку. Оновлення змісту, форм та методів навчання $i$ виховання в закладах освіти. 2012. Вип. 5. С. 99-102.

5. Богініч О. Основні механізми формування мотивації у майбутніх вихователів до фізкультурно-оздоровчої роботи 3 дошкільниками. Збірник наукових праць Уманського державного педагогічного університету імені Павла Тичини. 2009. Вип. 2. С. 38-47.

6. Бойченко Т. Здоров'язберігаюча компетентність як ключова в освіті України. Основи здоров'я $i$ фізична культура. 2008. Вип. 11-12. С. 6-7.

7. Венгер Л., Мухина В. Психология : монография. Москва : Просвешение, $1988.336 \mathrm{c.}$

8. Воронін Д. Формування здоров'язберігаючої компетентності студентів вищих навчальних закладів засобами фізичного виховання : автореф. дис. ... канд. пед. наук: 13.00.07. Херсон, 2006. $20 \mathrm{c}$.

9. Денисенко Н. Компетентностный подход в структурирование учебной дисциплины «теория и методика физического воспитания» как важная предпосылка для повышения качества подготовки учителя. Молодий вчений. 2018. Вип. 1. С. 296-300.

10.Державна національна програма «Освіта» («Україна XXI ст.»). URL: https://zakon.rada.gov.ua/laws/show/896-93$\% \mathrm{D} 0 \% \mathrm{BF} /$ print. 
11.Радуга. Примерная основная образовательная программа дошкольного образования / T. Доронова и др. Москва : Просвещение, $2006191 \mathrm{c.}$

12.Дошкільна освіта : словник-довідник: понад 1000 термінів, понять та назв / упор. К. Крутій, О. Фунтікова. Запоріжжя : ТОВ «ЛІПС Лтд.», 2010. 324 с.

13. Про національну безпеку України : Закон України. URL: https://zakon.rada.gov.ua/laws/show/2469-19\#Text.

14. Про освіту : Закон України. URL: https://zakon.rada.gov.ua/ laws/show/2145-19\#Text.

15.Зимняя И. Ключевые компетентности как результативноцелевая основа компетентностного подхода в образовании. Авторская версия. Москва : Исследовательский центр проблем качества подготовки специалистов, 2004. 42 с.

16.Зязюн I. Педагогічна майстерність: проблеми, пошуки, перспективи : монографія. Київ ; Глухів : РВВ ГДПУ, 2005. 118 с.

17.Конституція України. URL: https://zakon.rada.gov.ua/laws/ show/254\%D0\%BA/96-\%D0\%B2\%D1\%80\#Text.

18.Кошель А. Здоров'язбережувальна діяльність майбутніх вихователів дошкільних навчальних закладів у процесі професійного становлення. Вісник Чернігівського національного педагогічного університету імені Т.Г. Шевченка. Серія «Педагогічні науки». 2013. Вип. 110. С. 235-237.

19.Лисицын Ю. Слово о здоровье : монография. Москва : Академия, 2006. $192 \mathrm{c.}$

20. Мешко Г. Формування компетентності здоров'язбереження у майбутніх педагогів. Професійні компетениї та компетентності вчителя : матеріали Регіонального науково-практичного семінару. Тернопіль : Вид-во ТНПУ ім. В. Гнатюка, 2006. С. 17-21.

21. Міжгалузева комплексна програма «Здоров'я нації» на 2002-2011 pp. URL: https://zakon.rada.gov.ua/laws/show/14-2002$\% \mathrm{D} 0 \% \mathrm{BF} \#$ Text.

22. Московченко О. Оптимизация физических нагрузок на основе индивидуальной диагностики адаптивного состояния у занимающихся физической культурой и спортом (с применением компьютерных технологий) : автореф. дис. ... докт. пед. наук. Москва, 2008. 62 с.

23.Національна доктрина розвитку освіти. URL: https://zakon.rada.gov.ua/laws/show/347/2002\#Text.

24.Національна програма «Діти України». URL: https://zakon.rada.gov.ua/laws/show/63/96\#Text. 
25.Овчарук О. Компетентнісний підхід у сучасній освіті: світовий досвід та українські перспективи : монографія. Київ : K.I.C., 2004. 112 c.

26. Омеляненко В. Педагогіка. Завдання і ситуації. Практикум. Київ : Знання, 2006. 423 с.

27. Сергієнко В. Проблеми виховання студентської молоді. Вища школа. 2010. Вип. 7-8. С. 75-79.

28. Тамарская Н. Управление учебно-воспитательным процессом в классе (здоровьесберегающий аспект) : учебно-методическое пособие для учителя. Калининград : Изд-во КГУ, 2002. 31 с.

29. Химинець В. Компетентнісний підхід до професійного розвитку вчителя. Закарпатський інститут післядипломної педагогічної освіти. URL: http://zakinppo.ua/2010-01-18-13-4415/233-2010-08-25-07-10-49.

30.Холодная М. Психология интеллекта: парадоксы исследования : монография. 2-е изд., перераб. и доп. СанктПетербург : Питер, 2002. 272 с.

31.Шапар В. Психологічний тлумачний словник. Харків : Прапор, 2004. 640 c.

\section{Information about the author:} Kalichak Yurii Lvovych, Candidate of Pedagogical Sciences, Associate Professor Department of General Pedagogy and Preschool Education Ivan Franko State Pedagogical University in Drohobych 46, Lesia Ukrainka str., Drohobych, Lviv Region, Ukraine orcid.org/0000-0003-4348-1740 